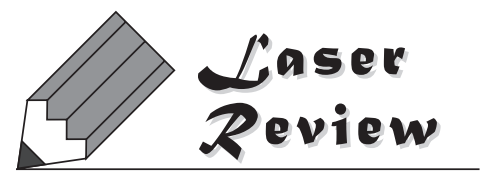

\title{
フェムト秒レーザー誘起ナノ構造による硬質薄膜のトライボロジー特性制御
}

\author{
安丸 尚樹 ${ }^{1}$, 宮崎 健創 ${ }^{2}$, 木内淳介 ${ }^{3}$ \\ 1福井工業高等専門学校 機械工学科 ( T916-8507 福井県鯖江市下司町) \\ 2京都大学エネルギー理工学研究所 (下611-0011 京都府宇治市五ヶ庄) \\ 3アイテック(株) 表面処理事業部（テ916-0016 福井県鯖江市神中町2-6-8）
}

\section{Control of Tribological Properties of Hard Thin Films with Femtosecond-Laser-Induced Nanostructuring}

\author{
Naoki YASUMARU, ${ }^{1}$ Kenzo MIYAZAKI, ${ }^{2}$ and Junsuke KIUCHI ${ }^{3}$ \\ ${ }^{1}$ Department of Mechanical Engineering, Fukui National College of Technology, Geshicho, Sabae, Fukui 916-8507 \\ ${ }^{2}$ Institute of Advanced Energy, Kyoto University, Gokasho, Uji, Kyoto 611-0011 \\ ${ }^{3}$ Surface Treatment Division, Eyetec Co., Ltd,.2-6-8 Kaminakacho, Sabae, Fukui 916-0016
}

(Received January 20, 2009)

\begin{abstract}
This paper reviews a new technology to control the tribological properties of hard thin film surfaces on which periodic nanostructures are produced by femtosecond (fs) laser ablation. The nanostructure was formed in an area more than $15 \times 15 \mathrm{~mm}^{2}$ on the surface of such thin films as diamond-like carbon (DLC) and TiN, using a target-scan system developed for fs-laser surface texturing. The friction properties of DLC film have been greatly improved by coating a $\mathrm{MoS}_{2}$ layer on a uniformly nanostructured surface, and the friction coefficient can be increased by a net-like patterning of the nanostructured area. The micro-tribological nature was also measured for the nanostructured surface. The results show that the tribological properties of the DLC surface can be controlled with fs-laser induced nanostructuring.
\end{abstract}

Key Words: Femtosecond-laser ablation, Nanostructure, Hard coating, Tribology, DLC

1. はじめに

気相コーティング技術の進歩により，トライボロジー 特性, 耐環境性, 生体親和性, 光学特性等に優れた高機 能硬質薄膜の開発とその応用例が急増している。例え ば，窒化チタン (TiN) などの窒化物・炭化物系セラミッ クス薄膜は, 高硬度で耐酸化性に優れた皮膜として, 金 型や工具類など機械関連分野への応用が普及している.

また, ダイヤモンド状炭素(Diamond Like Carbon: DLC) 薄膜は, 自動車部品, マイクロエレクトロニクス, バイ オ材料, 光学材料, MEMS等幅広い分野で期待されてお り，摩擦係数が極めて小さい平滑な膜であることから， 固体潤滑膜としてトライボロジー分野への応用が急速に 進展している1）。これらの硬質薄膜は硬くて脆い難加工 材で機械加工が難しく，化学的に除去することも極めて 困難である。一方，高強度なフェムト秒レーザーを用い ると, 各種材料について熱影響の少ない精密加工がで き，硬質薄膜の加工にも応用され始めている ${ }^{2,3}$.

また，レーザーテクスチャリングにより硬質薄膜の表 面をパターン化し, 摩擦係数を低減しようとする研究が
報告されている の薄膜表面に, 直径 $25 \sim 30 \mu \mathrm{m}$, 深さ15〜20 $\mu \mathrm{m}$ の穴を 周期的に加工することにより，トライボロジー特性を大 幅に向上させることに成功している ${ }^{4,5)}$. このような レーザーテクスチャリングは, 各種材料の摩擦特性を改 善するために研究されており7), テクスチャリングのサ イズはミクロンレベルまでが報告されている。一方，薄 膜に対するテクスチャリングは，薄膜本来の基板に対す る保護効果や密着力を維持するために, ナノメートルレ ベルのサイズであることやレーザー加工時の熱などによ るダメージができるだけ小さいことが必要となる場合が 多い.

筆者らは，TiNやDLCなどの硬質薄膜に対し，フェム ト秒レーザーパルスをアブレーションしきい值近傍の低 フルーエンスで照射すると, 照射部の薄膜表面にナノ メートルレベルの微細な周期構造が形成されることを見 出した ${ }^{8-12)}$. 直線偏光のレーザーパルスでは, 偏光方向 と直交する細長い構造が周期的に形成され，円偏光では ドット状の微細構造が形成された。 ナノ周期構造の平均 間隔は，波長の $1 / 10$ まで減少することが観察され，波長 
$267 \mathrm{~nm}$ の紫外フェムト秒レーザーにより, 約 $30 \mathrm{~nm} サ イ$ ズの周期的微細構造が硬質薄膜表面に加工された。レー ザー照射によって標的材料表面に生成することが知られ ているリップル構造 ${ }^{13,14)}$ と比較すると, このナノ構造の サイズははるかに小さい.

さらに，レーザー照射によりナノ構造が形成された DLC薄膜では, 同時に照射部がガラス状炭素 (Glassy Carbon: GC) に改質することを観測した ${ }^{9,12)}$. GC層は DLCより高い導電性や耐熱性を示し ${ }^{15)}$ ，DLCに新たな応 用分野が拡がる可能性を有している。

表面改質を含む十ノ周期構造生成のメカニズムについ ては, 実験結果を基に, 表面の微細な凹凸部で自由電子 が形成する局所的な増強電場 (近接場) と表面プラズモン ポラリトンの励起に拠るモデルが提唱され，偏光依存性や 波長依存性などの主な特性が矛盾なく説明されている ${ }^{16,17)}$.

本稿では，硬質薄膜表面へのフェムト秒レーザーによ るナノ構造形成に関する研究成果に基づき, 主にナノ構 造が形成されたDLC薄膜のトライボロジー特性について 紹介する ${ }^{18-20)}$ ，試料表面の広い範囲にナノ構造を均一に 加工するためのフェムト秒レーザー加工システムを開発 し, ボール・オン・ディスク型摩擦摩耗試験機により レーザー照射面の実荷重域のトライボロジー特性を評価 した ${ }^{18)}$ 。その結果, ナノ構造が平面状に均一に形成され たDLC膜は，表面に二硫化モリブデン $\left(\mathrm{MoS}_{2}\right)$ を被覆す ると摩擦係数が大幅に低下すること, さらにナノ構造を 網目状にパターン化して形成させると逆に摩擦係数が増 加することを見出した，また，マイクロトライボロジー 特性として, $1000 \mu \mathrm{N}$ および $0.1 \mu \mathrm{N}$ 付近の微小荷重で測 定された摩擦特性を報告する ${ }^{19,20)}$ 。これらの結果は, DLC薄膜などの硬質薄膜に形成されるナノ構造を最適化 することにより，トライボロジー特性を広範囲に制御で きることを示している.

\section{2. ナノ構造のレーザーテクスチャリングと トライボロジー特性の制御}

\section{1 ナノ構造のレーザーテクスチャリングシステム}

トライボロジー特性の制御を目的とした表面設計技術 を開発するために, 硬質薄膜としては近年トライボロ ジー分野への応用展開が著しいDLC薄膜を加工対象とし た. 基板としては鏡面研磨された純チタン板 (JIS2種, 厚さ $2 \mathrm{~mm}$ ) とステンレス鋼 (SUS304, 厚さ $1 \mathrm{~mm}$ )を用い た。 DLC薄膜は，非平衡マグネトロンスパッタリング装 置 ( 株) 神戸製鋼所製)をバイアス電位 $150 \mathrm{Vで}$ 稼働し, カーボンのターゲットを用いて, $\mathrm{Ar}$ と $\% \mathrm{CH}_{4}$ の混合ガ ス中で被覆した。実験には膜厚1.4 $\mu \mathrm{m}$, 硬度HV3000, 表面粗さ9 $\mathrm{nm}$ のLC薄膜を用いた。

ナノ構造をトライボロジー特性の最適化等に応用する ためには，ナノ構造を均一に大面積に形成する技術を開 発することが必要になる。著者らは，ナノ構造をパター ン化してある程度の面積にテクスチャリング加工ができ るフェムト秒レーザーシステムを開発し, その加工条件 を検討した ${ }^{18)}$. DLCを被覆した基板を精密3軸ステージ
にセットし，フェムト秒レーザーを大気中で試料面に直 角に照射した。用いたレーザーパルスは，波長 $800 \mathrm{~nm}$, パルス幅100 fs, 繰り返し周波数 $1 \mathrm{kHz}$ で, 直線偏光して いる。焦点距離500 $\mathrm{mm}$ の凹面反射鏡 (放物鏡)にて集光

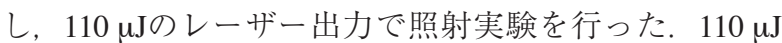
のレーザーフルーエンスは $0.14 \mathrm{~J} / \mathrm{cm}^{2} に$ 対応しており, 文献 (9)に記されたDLC薄膜のアブレーションしきい值 $0.11 \mathrm{~J} / \mathrm{cm}^{2}$ 近傍のフルーエンスである。DLC薄膜をセッ トしたステージを一定速度でスキャンさせ，同一場所の 打ち込みパルス数が約 150 パルスとなるように調整し た。1回の直線状スキャンでアブレーション加工された 線幅 $D$ は約 $240 \mu \mathrm{m}$ であった。

照射方法としては，Fig. 1に示すように，（a）直線状の 走査線を距離 $L$ だけ平行にずらしながら行う平面状照射

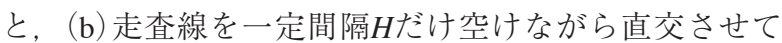
行う網目状照射の二種類を行った ${ }^{18)}$ （a）タイプの照射 は均一にナノ構造が加工された平面を得るために，(b) タイプはレーザーテクスチャリング的手法によりナノ構 造が加工された領域を周期的に形成させるために行っ た。なお， $L=D / 2=120 \mu \mathrm{m}, H=2 D=480 \mu \mathrm{m}$ とし，照 射面積は最大で $15 \mathrm{~mm} \times 15 \mathrm{~mm}$ とした。

また，ナノ構造が形成されたDLC薄膜表面に二硫化モ リブデン $\mathrm{MoS}_{2}$ をスパッタリングにより $0.5 \sim 1 \mu \mathrm{m}$ 蒸着 し, 低硬度の潤滑膜が被覆された場合のトライボロジー 特性も評価した。

レーザー照射面のナノ構造の形態は電界放射型走査電 子顕微鏡 $(\mathrm{FE}-\mathrm{SEM})$ を用いて高分解能で観察し，照射部 の表面粗さおよび加工痕深さは走査型プローブ顕微鏡 (SPM)を用いて計測した。DLC薄膜表面は極微ラマン分 光分析装置(スポット径 $1 \mu \mathrm{m}$ )を用いて状態分析を行い, レーザー照射による改質状況を調べた。

2.2 平面状・網目状にテクスチャリングされたナノ 構造と表面改質

Fig. 2 (a) は平面状照射 $(L=120 \mu \mathrm{m}), \quad$ （b）は網目状照 射 $(H=480 \mu \mathrm{m})$ で加工されたDLC薄膜表面のSEM写真を 示す ${ }^{18)}$. レーザーの走査により形成される試料表面のう

(a)

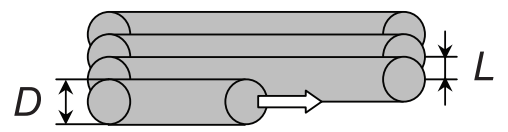

(b)

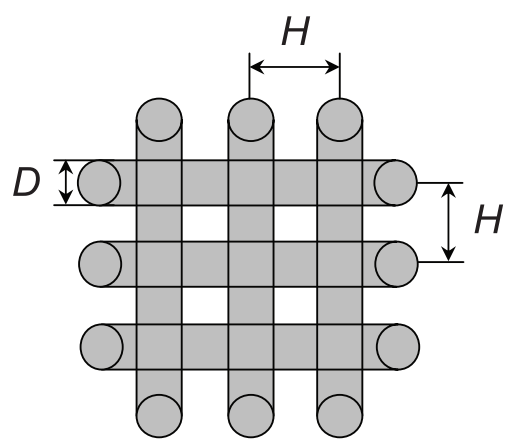

Fig. 1 Schematic diagram of the laser scan for (a) the uniformly nanostructured surface and (b) the netlike patterning of the nanostructured area. 

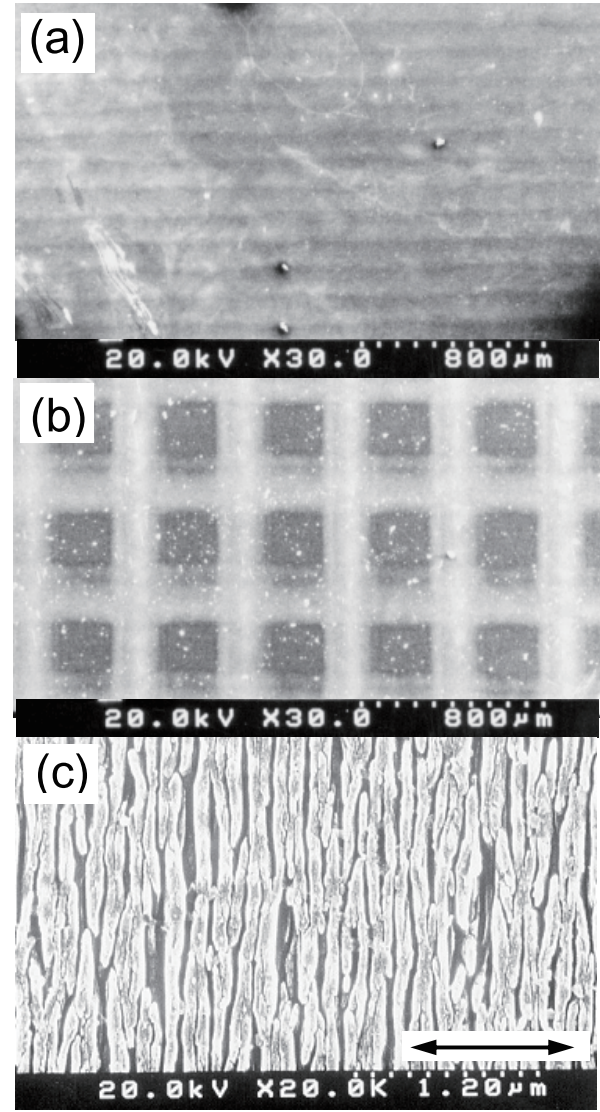

Fig. 2 SEM images of the DLC surfaces irradiated with fs pulses of (a) the parallel scan and (b) the crossed scan along a net-like pattern, and (c) the image of nanostructured surface. The image magnifications are 30 for (a) and (b), and 20,000 for (c). The arrow indicates the polarization direction of fs laser pulses.

ねりをSPMにより測定したところ $10 \mathrm{~nm}$ 以下と小さく， 走査線の影響はほとんどないことが判明した。

Fig. 2 (c) はレーザー照射面に扮ける2万倍のSEM像であ り，レーザーを照射した全面に扔いて，レーザーの偏光 方向に直交した向きに配向したナノ構造が形成されてい るのが確認された ${ }^{18}$. 周期的に形成されているナノ構造 の平均間隔は約 $120 \mathrm{~nm}$ であり, 以前の著者らの報告と 同様に，使用されているレーザー波長よりはるかに小さ い.

また，DLCの場合，ナノ構造が形成されるレーザーの 照射条件で，照射面がGCに改質されることが見出され ている ${ }^{9,12)}$. 今回平面状に形成されたナノ構造形成面を ラマン分光で詳細に分析した，その結果，レーザー照射 面の全面からFig. 3 (a) に示すラマンスペクトルが得ら れ，(b)の未照射部DLCからのラマンスペクトルと比較 して, 照射面がほぼ均一にGCに改質されていることが 明らかとなった18,21)。

2.3 ナノ構造形成面のトライボロジー特性(実荷重域)

2.3.1 平面状にテクスチャリングされたナノ構造の 特性

実荷重域に扔ける十ノ構造が形成されたDLC薄膜の卜 ライボロジー特性を調べるために, 大気中でボール・オ

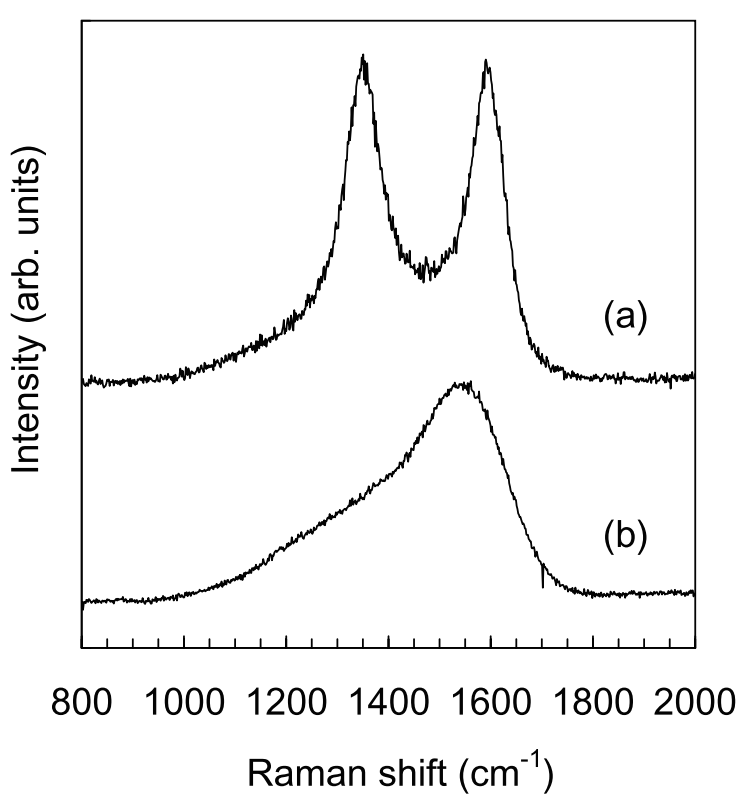

Fig. 3 Raman spectra of (a) the nanostructured DLC film and (b) the non-irradiated film.

ン・ディスク型摩擦摩耗試験機を用いて, 摩擦係数の変 化を回転数 $R=10^{4}$ 回までモニタリングした。試料ボール は6 mmの超硬ボール(WC-Co, HV1600) と軸受鋼SUJ2 ボール（HV600）を用い, 摩擦速度は $30 \mathrm{~mm} / \mathrm{s}$ と一定で, 回転半径は3〜 $5 \mathrm{~mm}$, 荷重は $2 \sim 10 \mathrm{~N}$ を用いた。

Fig. 1 (a)に示す平面状照射により，ナノ構造を平面 状にテクスチャリングされたDLC薄膜に対し摩擦係数を 測定した．Fig. 4に，荷重W=10 Nで測定した結果を未 照射のDLC薄膜と比較して示す ${ }^{18}$ 。ここで (a) は軸受鋼 ボールに対しR=2,000回転後，(b)は超硬ボールに対し $R=10^{4}$ 回転後の摩擦係数である。十ノ構造が形成された DLC薄膜表面の摩擦係数は, 軸受鋼では未照射材の約 8 割となり,レーザー照射により摩擦係数が低減する傾向 を示した。これは照射によってDLC表面に軟質な改質層 が形成されたことにより，凝着性の高い軸受鋼に対して 良好な摩擦摩耗条件が得られたためと考元られる。一 方, 超硬ボールに対しての摩擦倸数は約 0.08 となり, 軸 受鋼ボールより值が小さく未照射材と比較してほとんど 変化しないことが判明した。これは超硬ボールの高硬度 と低凝着性の特性のためと考えられる。

次に, DLC薄膜のナノ構造形成面に潤滑性に優れた低

(a) Steel ball

(b) WC-Co ball

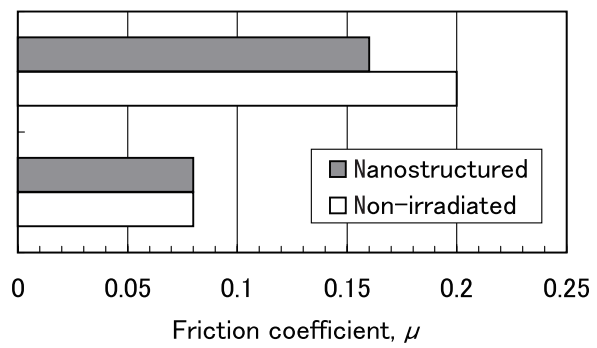

Fig. 4 Friction coefficients of the nanostructured DLC film (shaded bar) and the non-irradiated DLC (white bar) measured under the load $W=10 \mathrm{~N}$ with (a) the steel ball at $R=2,000$ and (b) the WC-Co ball at $R=10^{4}$. 
(a) Steel ball

(b) WC-Co ball

(c) WC-Co ball

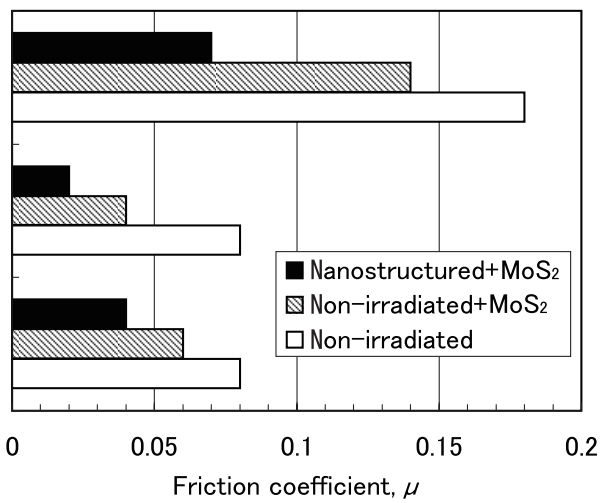

Fig. 5 Friction coefficients of the nanostructured DLC with $\mathrm{MoS}_{2}$ coating (black bar), the non-irradiated DLC with $\mathrm{MoS}_{2}$ coating (hatched bar), and the nonirradiated DLC (white bar). Each group represents the results measured with (a) the steel ball at $W=$ $2 \mathrm{~N}$ and $R=10^{4}$, (b) the WC-Co ball at $W=10 \mathrm{~N}$ and $R=4,000$, and (c) the WC-Co at $W=10 \mathrm{~N}$ and $R=10^{4}$.

硬度 $\mathrm{MoS}_{2}$ 薄膜を被覆し, トライボロジー特性を調ベ た. Fig. 5は, ナノ構造形成後MoS 2 を被覆したDLC薄 膜, $\mathrm{MoS}_{2}$ を被覆した未照射のDLC薄膜, DLC薄膜のみ の3種類の摩擦係数を比較している ${ }^{18)}$. (a)は軸受鋼ボー ル (荷重 $2 \mathrm{~N})$ に対し $R=10^{4}$ 回転後の結果, (b) は超硬ボー ル (荷重 $10 \mathrm{~N})$ に対 $L R=4,000$ 回転後の結果, (c) は $R=10^{4}$ 回転後の結果をそれぞれ示している. これらの結 果は, DLC薄膜の摩擦特性に与える $\mathrm{MoS}_{2}$ 層の優れた効 果を明確に示している。例えば (a)の軸受鋼ボールの場 合では, ナノ構造形成面への $\mathrm{MoS}_{2}$ 被覆により, 摩擦係 数は未照射材の約 $2 / 5$ に低減している。一方, 未照射材 への $\mathrm{MoS}_{2}$ 被覆では, 摩擦係数は約 $3 / 4 の$ 低減となってい る。 $\mathrm{MoS}_{2}$ 被覆による摩擦係数の大幅な低減効果は, (b) ならびに(c)でも確認できる。未照射材の約 $1 / 4$ という最 も顕著な低下は (b) の超硬ボール4,000回転で観測され, 摩擦係数は 0.02 という最小值を示した。 ナノ構造形成後 $\mathrm{MoS}_{2}$ 被覆により摩擦係数が大幅に低減するのは, 表面 のナノ構造が移動しやすい $\mathrm{MoS}_{2}$ 層を蓄える油溜めの効 果を示すこと, 低硬度のGCに改質された表面層が $\mathrm{MoS}_{2}$ の保持効果を向上させることが原因と考えられる。

ナノ構造をDLC薄膜表面に均一に形成後 $\mathrm{MoS}_{2}$ を被覆 することにより, 指定領域の摩擦係数を大幅に低下させ る表面設計技術として応用できる。

\subsection{2 網目状にテクスチャリングされたナノ構造の} 特性

Fig. 1 (b)に示す網目状照射により, ナノ構造を網目 状にテクスチャリングされたDLC薄膜に対し, 平面状照 射の場合と同様な試験法で摩擦係数を測定した. Fig. 6 は，10 Nの荷重で，（a）軸受鋼と（b) 超硬ボールにより測 定された結果を未照射材と比較して示す ${ }^{18)}$ 。網目状照射 の場合, 両ボールとも摩擦係数および振動が大きく, 軸 受鋼ボールに対しては $R=187$ 回転, 超硬ボールに対し ては $R=52$ 回転で測定を中止した. Fig. 6のように, 超 硬ボールに対しては摩擦係数が未処理材の 0.08 から 0.45 (a) Steel ball

(b) WC-Co ball

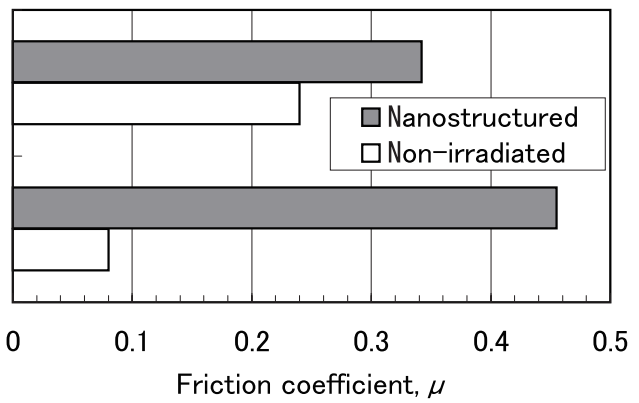

Fig. 6 Friction coefficients of the DLC film partially nanostructured with the net-like pattern (shaded bar) and of the non-irradiated DLC (white bar), measured at $W=10 \mathrm{~N}$ with (a) the steel ball and (b) the WC-Co ball. In (a) and (b), the revolutions $R=$ 187 and $R=52$ were used, respectively, for the partially nanostructured DLC, and $R=10^{4}$ for the non-irradiated DLC.

に顕著に増加した。 この摩擦係数の急激な増加は, 以下 に記すように，ナノ構造形成領域のパターン加工により 試料表面の硬度が空間的に変動することが影響するため と考えられる。すなわち, この照射条件ではフルーエン スがアブレーションしきい值近傍と小さいため, 表面粗 さはほとんど影響を受けない。実際，SPMで測定された 照射部の表面のうねりの大きさは10 nmのオーダーであ り，摩擦試験の結果には影響を与えないと判断される. 一方, ナノ構造が形成されるレーザー照射の条件で, DLCからGCに構造が変化することにより薄膜表面の照 射部の硬度が低下する。網目状照射によりパターン化さ れたナノ構造形成領域は2 $40 \mu \mathrm{m}$ の周期で表面硬度の空 間的変動を生じるため, DLC薄膜の摩擦係数が増加する と考えられる。

網目状照射の線幅 $D$ と線間隔 $H$ を変化させて摩擦係数 の増加量を調整することにより, DLC薄膜表面の起伏を ほとんど変化させずに，指定領域の摩擦係数を増加させ る表面設計技術として応用できる.

\section{4 ナノ構造形成面のマイクロトライボロジー特性 （微小荷重域）}

DLC薄膜に対するナノ構造形成面の微小荷重域のマイ クロトライボロジー特性としては, (A) 1,000 $\mu \mathrm{N}$ おび (B) $0.1 \mu \mathrm{N}$ 付近の荷重での摩擦特性を調べた.

（A）1,000 $\mu \mathrm{N}$ の荷重域は，SPMに付属されたTriboscope (Hysitron社)によるナノスクラッチ試験を用いて評価し た ${ }^{19)}$. 先端半径 $1 \mu \mathrm{m}$ のダイヤモンドチップにより，摩擦 係数の変化を $10 \mu \mathrm{m}$ のスクラッチ長さに対し計測した。

直線偏光のレーザーの照射面には，Fig. 2 (c)に示す ように, 偏光方向と直交して細長い粒状のナノ構造が形 成されている。レーザーの偏光方向に直交した方向でナ ノ構造形成面の摩擦係数を $1,000 \mu \mathrm{N}$ の荷重で測定したと ころ, 約 0.25 の值を示した。なお，レーザー偏光に平行 な方向で求めた摩擦係数は, 約 $20 \%$ 増加していた。 た，未照射のDLC薄膜は約 $0.1 の$ 摩擦係数を示した。未 照射材より摩擦係数が増加する理由は, ナノ構造の凹凸 による抵抗力の増加とGC改質による表面硬度の低下が 
影響していると考えられる。実際，測定用チップの押し 込み深さは，未照射材の約 $30 \mathrm{~nm}$ から照射材は約 $120 \mathrm{~nm}$ に増加しており, その分チップにかかる摩擦力が増加し ている.

この荷重域ではナノ構造形成部のみの摩擦係数を増加 させることができるため, 局部的に摩擦係数を増加させ る技術としての利用が考えられる。また，レーザー照射 部はGCに改質され導電特性が向上するため, 絶縁性の DLC内に局部的に導電性を有し, 摩擦係数の増加したパ スやスポットを加工する目的に応用できる。

(B) $0.1 \mu \mathrm{N}$ の荷重域は，環境制御可能なチャンバー内 に設置した原子間力顕微鏡 $(\mathrm{AFM})$ を用いた摩擦試験の 結果を報告する ${ }^{20)}$. 垂直荷重を20〜130 nNと変化させ, 測定範囲 $1 \mu \mathrm{m} \times 1 \mu \mathrm{m}$, すべり速度 $2 \mu \mathrm{m} / \mathrm{s}$ として，コンタ クトモード(垂直荷重一定)で測定した。ナノ構造を付与 した表面を測定するためのプローブには，市販のカンチ レバーにガラス球 (JIS 試験用粉体2 (GBM20), 直径 $22 \mu \mathrm{m})$ を接着したガラス球探針を用いている.

DLC薄膜のナノ構造形成面の摩擦力 (水平力) を測定し 未照射材と比較すると, 摩擦力が約 $1 / 3$ と大幅に低減す ることが判明した。 また, 引き離し力も未照射材と比較 して約1/4と大幅に低減していた。超微小荷重域では, 微小な表面粗さが凝着力を大きく減少させ，摩擦係数を 小さくすることが指摘されている ${ }^{22,23)}$. ナノ構造形成面 では表面に形成される周期的微細構造により接触面積が 小さくなり，摩擦力や引き離し力が低下したと判断され る。

\section{3. おわりに}

フェムト秒レーザーパルスを硬質薄膜に照射して，表 面に形成されるナノ構造のサイズ・形状を制御する加工 技術 $^{8-12,18)}$ は，かなり確立されたものになってきてい る。また, 最近の研究によって, ナノ周期構造生成過程 の詳細も明らかにされつつある ${ }^{16,17)}$.

本稿では，フェムト秒レーザーによる硬質薄膜表面へ のナノ構造形成技術とトライボロジー特性制御法への応 用について，DLC薄膜を中心に紹介した。自動車産業等 の実荷重域では, 平面状のレーザーテクスチャリングに よりナノ構造を均一に加工後 $\mathrm{MoS}_{2}$ を被覆することによ り，指定領域の摩擦係数を大幅に低下できることを示し た。一方，ナノ構造の網目状のテクスチャリングは，表 面の起伏をほとんど変化させずに指定領域の摩擦係数を 大幅に増加させた。このようにナノ構造のテクスチャリ ングにより，摩擦係数を非常に微小な值から大きな值ま で制御した表面を設計することが可能である.

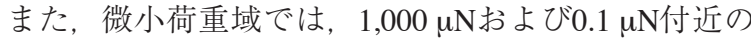
荷重での摩擦特性を紹介した。前者ではナノ構造形成部 の摩擦係数が増加する方向に変化するため, 絶縁性の DLC内に局部的に導電性を有し，摩擦係数の増加したパ スやスポットを加工する技術への応用を示した。また後 者の超微小荷重では，表面のナノ構造により接触面積が 小さくなり，摩擦力や引き離し力が大幅に低減する現象 が生じる.

以上のように，フェムト秒レーザーの特徴を生かした 硬質薄膜表面へのナノ構造加工技術は，幅広い荷重領域 に対応した次世代表面設計技術に発展することが期待さ れる。

\section{参考文献}

1) See, for example, C. Donnet and A. Erdemir: Tribology of DiamondLike Carbon Films (Springer, New York, 2008).

2) J. Bonse, M. Geuß, S. Baudach, H. Sturm, and W. Kautek: Appl. Phys. A 69 (1999) S399.

3) J. Bonse, H. Sturm, D. Schmidt, and W. Kautek: Appl. Phys. A 71 (2000) 657.

4) G. Dumitru, V. Romano, H.P. Weber, S. Pimenov, T. Kononenko, J. Hermann, S. Bruneau, Y. Gerbig, and M. Shupegin: Diamond Rel. Mater. 12 (2003) 1034

5) G. Dumitru, V. Romano, Y. Gerbig, H. P. Weber, and H. Haefke: Appl. Phys. A 80 (2005) 283

6) A. Erdemir: Tribol. Int. 38 (2005) 249.

7) I. Etsion: Trans. ASME J. Tribol. 127 (2005) 248.

8) N. Yasumaru, K. Miyazaki, and J. Kiuchi: Appl. Phys. A 76 (2003) 983.

9) N. Yasumaru, K. Miyazaki, and J. Kiuchi: Appl. Phys. A 79 (2004) 425.

10) K. Miyazaki, N. Maekawa, W. Kobayashi, M. Kaku, N. Yasumaru, and J. Kiuchi: Appl. Phys. A 80 (2005) 17.

11) N. Yasumaru, K. Miyazaki, and J. Kiuchi: Appl. Phys. A 81 (2005) 933.

12）安丸 尚樹, 宮崎 健創, 木内 淳介：レーザー研究 33 (2005), 519.

13) See, for example, D. Bäuerle: Laser Processing and Chemistry (Springer, Berlin, 1996) Chap. 28.

14) J. Reif, F. Costache, M. Henyk, and S. V. Pandelov: Appl. Surf. Sci. 197-198 (2002) 891, and references therein.

15) A. Dekanski, J. Stevanovic, R. Stevanovic, B. Z. Nikolic, and V. M. Jovanovic: Carbon, 39 (2001) 1195, and references therein

16) G. Miyaji and K. Miyazaki: Appl. Phys. Lett. 89 (2006) 191902; 91 (2007) 123102.

17) G. Miyaji and K. Miyazaki: Opt. Express 16 (2008) 16265.

18) N. Yasumaru, K. Miyazaki, and J. Kiuchi: Appl. Surf. Sci. 254 (2008) 2364

19) N. Yasumaru, K. Miyazaki, J. Kiuchi, and K. Komai: Proc. 8th Int. Symp. on Laser Precision Microfabrication (LPM2007), Vienna, April, \#07-18: P-73 (2007).

20) A. Mizuno, T. Honda, J. Kiuchi, Y. Iwai, N. Yasumaru, and K. Miyazaki: Tribology Online 1 (2006) 44

21) M. Yoshikawa, N. Nagai, M. Matsuki, H. Fukuda, G. Katagiri, H. Ishida, A. Ishitani, and I. Nagai: Phys. Rev. B 46 (1992) 7169.

22）安藤泰久, 田中敏幸, 伊能二郎, 角田和雄: 日本機械学 会論文集 (C編) 65 (1999) 3784.

23) 安藤 泰久：精密工学会誌 67 (2001) 1916. 
ガラス状炭素 (glassy carbon: GC)

ガラス状炭素は黒いガラスのような外観をしており， 破面がガラスに類似していることから命名された。グラ ファイトの一種であり, 結晶子サイズが約 $3 \mathrm{~nm}$ と非常 に小さい硬質炭素材である。 バルク材は熱硬化性樹脂を 高温で処理(炭素化)することによって得られ, 耐摩耗 性・耐食性・耐久性・低反応性に優れ，不純物がでにく
い高精度な電極材や半導体関連部品等に製品化され，燃 料電池, ハードディスク用基板, ロケット等への応用が 検討されている。摩擦摩耗特性ではDLC (ダイヤモンド 状炭素) 薄膜が注目されているが，GCはDLCにない耐熱 性・耐酸化性や導電性にも優れた硬質炭素材として期待 されている。

(安丸 尚樹)

\author{
トライボロジー(tribology) \\ トライボロジーとはギリシャ語のtribos(摩擦)を語源
} とした造語で, 固体の摩擦・摩耗・潤滑を扱う工学分野 を指し，相対運動を行いながら相互作用を及ぼし合う表 面，ならびにこれに関連した諸問題と応用に関する科学 技術と定義されている。 トライボロジーが扱うものは, 自動車など一般工業製品から微小荷重域のマイクロマシ
ンや人工関節等のバイオ製品など幅広い分野・領域にわ たっている。この特性に優れた材料はトライボマテリア ルと呼ばれており, 高硬度で表面平滑性, 摺動特性, 化 学的安定性等に優れたDLC (ダイヤモンド状炭素) 薄膜 が，非常に期待される材料として応用展開が急速に進ん でいる。

(安丸 尚樹) 